\title{
THE EXTENT OF AGRICULTURAL LAND DAMAGE IN VARIOUS TSUNAMI WAVE HEIGHT SCENARIOS: DISASTER MANAGEMENT AND MITIGATION
}

\author{
S. Antoni ${ }^{1}$, R. A. Bantan ${ }^{1}$, H. M. Taki ${ }^{2}$, W. Anurogo ${ }^{3}$, M. Z. Lubis ${ }^{3}$, T.A. Al Dubai ${ }^{1}$, Aaid G. Al-Zubieri ${ }^{1}$ \\ ${ }^{1}$ Marine Geology Department, Faculty of Marine Sciences, King Abdulaziz University, Jeddah 21589, Saudi Arabia - \\ (satria.scientist@yahoo.com,rbantan@kau.edu.sa, talhadubai@yahoo.com, aaid222@yahoo.com) \\ ${ }^{2}$ Department of Urban and Regional Planning, Faculty of Environmental Design, King Abdulaziz University, Jeddah 21589. \\ Saudi Arabia - htaki0001@stu.kau.edu.sa \\ ${ }^{3}$ Geomatics Engineering, Batam State Polytechnic, Batam 29461, Indonesia - (wenang@ polibatam.ac.id, \\ lubiszainuddin@gmail.com)
}

KEY WORDS: Tsunami, Run-up Modelling, Remote Sensing, Risk Management and Mitigation

\begin{abstract}
:
The southern coastal areas of Java are highly vulnerable areas of earthquake hazard because they located $200 \mathrm{~km}$ from the southern Java subduction zone. This zone is an active seismicity area, resulting in many tectonic earthquakes caused by collisions and shift between the plates. This shift when it occurs under the sea surface with a large power intensity can lead to a tsunami. This research conducted to identify the extent of agricultural land (AL) damaged by the tsunami for disaster risk management and mitigation. Numerical modelling was performed to determine the run-up height of the tsunami through numerical data. This model was designed using the worst-case scenario. The tsunami inundation model analysed from the coming wave (run-up) with a height of $30 \mathrm{~m}$. This model used scenarios of tsunami run-up height in a coastline, coarse coefficient and slope. The data extracted using remote sensing (RS) data was the slope obtained from the ASTER image GDEM data, the agricultural land productivity data obtained using NDVI vegetation index transformation and field data on productivity, and tsunami hazard analysis with various altitude scenarios using run-up model impact on existing AL conditions. The elevation-data was obtained from the 15-meter ASTER image data (GDEM) that was reclassified into a slope class map. The risk of destruction of AL based on wave height extracted by using RS data generated rice risk loss index of AL of 190.5071-tons for a height of $1 \mathrm{~m}, 1851.522$-tons for a height of $5 \mathrm{~m}, 7402.71$-tons for a height of $10 \mathrm{~m}, 10776.47$-tons to a height of 15-meters, 11823.9-tons for height 20-meters, and 11824.27-tons to a height of 30-meters.
\end{abstract}

\section{INTRODUCTION}

The archipelago lies in a region that is a meeting of the highly active plates of the Earth, namely Eurasia, Australia, the Pacific and the Philippines (Tumonggor et al. 2013). So it is an area very vulnerable to tectonic earthquakes (Nugraha et al., 2015). The quakes were partially centered on the Indian Ocean floor and some could trigger major ocean waves called tsunamis (Wang ang Liu, 2006). Some coastal areas of Indonesia are very potential tsunami affected coastal areas of the islands that overlook the Pacific Ocean and the Indian Ocean. Tsunamis are formed from major disturbances in deep seas such as cesarean or earthquake movements, volcanic eruptions or caldera collapse, landslides, meteor collisions, and the like (Berryman, 2006). As it approaches the shallow oceans, the energy at long waves is compressed into short waves, thus making waves with a formation like a high wall (Khoirunnisa et al., 2017; Lubis et al., 2017). The maximum height of a tsunami measured from sea level is called run-up. The tsunami run-up is the vertical distance between the maximum height reached by the waves on the shore and the mean sea surface level (Eckert et al., 2012). If the Tsunami wave is not a break, the run-up height is about the same as its original height. However, if the tsunami wave is a breaking wave (bore or surge wave), then the kinetic energy stored will change the run-up height greater and form the waves rotate. The area of the fault and the magnitude of the earthquake has a strong link to determine the parameters of the Tsunami scale characteristics (Carpenter, 2005). The relationship between earthquake magnitude and tsunami run-up height is shown in table 1.

\begin{tabular}{ccc}
\hline No & $\begin{array}{c}\text { Earthquake } \\
\text { Magnitude (SR) }\end{array}$ & $\begin{array}{c}\text { Maximum run-up waves } \\
\text { (meters) }\end{array}$ \\
\hline $\mathbf{1}$ & $<6$ & $<0.5$ \\
\hline $\mathbf{2}$ & $6-7$ & $0.5-1.5$ \\
\hline $\mathbf{3}$ & $7-8$ & $1.5-6.0$ \\
\hline $\mathbf{4}$ & $>8$ & $>6.0$ \\
\hline & & Source: Carpenter, 2005
\end{tabular}

Table 1. The relationship between earthquake magnitude and tsunami run-up height

The southern coastal area of Java and its surrounding areas are highly vulnerable areas of earthquake hazard since this area is located $200 \mathrm{~km}$ south of the southern Java subduction zone (Khomarudin et al., 2010). This plate boundary area is an active seismicity zone, resulting in many tectonic earthquakes caused by collisions between the plates. The location adjacent to the boundary between these plates resulted in these areas vulnerable to the seismic activity caused by the shift between the plates. This shift of the plate when it occurs under the surface of the sea with a large power intensity can lead to a tsunami (Reese et al., 2007).

Hazards and vulnerabilities are part of the risk assessment. Risk assessment is a process for determining risk behavior and symptoms by analyzing the potential for disaster on existing vulnerabilities in which conditions can cause harm and damage to people, property, physical and social environments (Reese et al., 2007).

Tsunami disaster is a long wave that emerged as a result of disruption of the surface and the seabed by the movement of the earth's crust due to the submarine earthquake. The tsunami period typically ranges from a few minutes to tens of minutes. The height of the tsunami wave is the vertical 
distance between the wave peak and the zero point of the sea surface, which will then expand as the tsunami waves propagate near the coast. The tsunami wave height will reach maximum at shore like $\mathrm{U}$ or $\mathrm{V}$, for example in a bay or river mouth. Characteristics of submarine earthquakes that cause tsunamis are earthquakes occurring in subduction zones that have magnitudes over 6 on the Richter scale, with a depth of less than $100 \mathrm{~km}$ (Matsumaru et al, 2012) Bantul Regency is a potential area of tsunami disaster because it is adjacent to the subduction zone (Hartoko et al., 2016). Based on the above mentioned, Bantul regency needs to prepare a well-integrated tsunami disaster management model.

Bantul Regency, almost half of the area, is a farming cultivation area with a high level of fertility with technical irrigation supported in most of the existing rice fields. The proportion of land use according to National Land Agency (BPN) data of Bantul Regency covers mixed gardens covering $16,602,4557$ ha $(32,76 \%)$, rice field $16,046,22$ ha $(31,66 \%)$, moor $6,637,39$ ha $(13.10 \%)$, villages covering $3,810.78$ ha $(7.52 \%), 1,385.00$ ha $(2.73 \%)$, barren land area of 573.00 ha $(1.13 \%)$, and other land use area of 5,630.21 ha $(11.11 \%)$. The lands scattered in Bangunharjo and Panggungharjo villages are mostly used for housing and office buildings. The two villages are densely populated and bordered by Yogyakarta City. Other sub-districts are the most frequent narrowing of paddy fields in Banguntapan, Kasihan, and Bantul Subdistricts (Bantul, B. P. S. K., 2016).

In the process of preparation of local policy making on disaster management which is integrated with coastal area development activity, it is necessary to make the spatial planning of coastal area based on disaster management (Pomeroy et al., 2006). To implement the plan required a spatial model and a mathematical simulation model to be used as a reference in preparing the zoning of coastal areas supported by spatial data (Shalaby and Tateishi, 2007). Data derived from satellites have the carrying capacity for the handling of natural disasters occurring in Indonesia, especially after the devastating earthquakes and tsunamis that hit areas such as Aceh and Pangandaran that occurred in December 2004 and July 2006 (Koshimura et al., 2009). Satellites such as LANDSAT, SPOT, IKONOS, QUICKBIRD, ERS, or ENVISAT in its development provides many advantages in monitoring at any time. Many remote sensing techniques based on natural resources satellites that can be used to interact with the object under study (Anorogo et al 2017; Lubis et al, 2017), most of the data used to conduct the study are Landsat image data, whereas there is another image whose resolution is higher than the predecessor satellite image, so that in this research used ASTER image to test ASTER image capability in knowing areas of agricultural land affected by various tsunami scenarios. Remote sensing technology combined with GIS (Geographic Information System) is done by integrating spatial data to enhance the accuracy of the information (Anorogo et al. 2017; Lubis et al., 2017) it wants to generate, to know the areas of agricultural land affected by various types of high-tsunami scenarios.

\section{METHODS}

The research method is a step that must be done to complete the research objectives to be achieved. This research conducted to identify the extent of agricultural land damage in various tsunami wave height scenarios as the basis for disaster risk management and mitigation. Geographically Bantul Regency is located between $110^{\circ} 12$ ' $34^{\prime}$ to $110^{\circ} 31$ '08' 'East Longitude and between $7^{\circ} 44^{\prime} 4$ 'to $8^{\circ} 00^{\prime} 27$ " south latitude. Bantul Regency is one of five regions in the Special Province of Yogyakarta. The total area of $506.85 \mathrm{~km}_{2}$ (15.90\% of the total area of DIY Province) with topography as a lowland of $40 \%$ and more than half $(60 \%)$ hilly areas. The western part is a sloping area and hills stretching from North to South covering $89.86 \mathrm{~km}_{2}(17.73 \%)$. The Central part is a flat and sloping area which is a fertile agricultural area of $210.94 \mathrm{~km}_{2}(41.62 \%)$. Eastern part is a sloping, sloping and steep terrain of $206.05 \mathrm{~km}_{2}$ (40. 5\%). While in the southern part of the sandy and slightly plateau, stretching on the South Coast from Srandakan, Sanden, and Kretek. The location of the study was selected in Bantul district because Bantul's agricultural sector contributes substantially to the economy and has fertile agricultural land so that agricultural activities can flourish, therefore it is necessary to anticipate the destruction of agricultural land which one of the possibilities can be caused by tsunami waves by making some scenario of tsunami wave and its effect on the agricultural land condition.

The location of the research is shown in figure 1 .

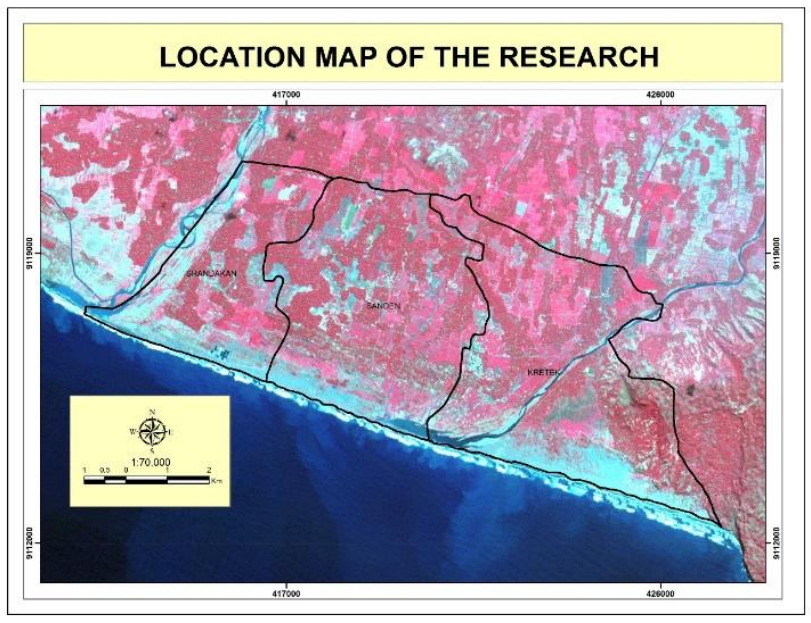

Figure 1. Location map of the research

The research begins with a preliminary study of the occurrence of tsunamis and the impact of the tsunami disaster on agricultural land. This preliminary study is intended to collect data and information about tsunami disaster in Bantul District with the location of research are some districts adjacent to the coast which is assumed to be vulnerable to the tsunami disaster. At this stage will be done data collection activities both primary and secondary data. Primary data obtained from remote sensing data and through observation and survey at research sites (sub-districts adjacent to coastal areas), while secondary data collection is done through the searching of various libraries that exist in various government agencies and private as well as on the internet. The data to be collected consists of spatial and nonspatial data in the form of maps, and research reports. The next stage is the stage of data analysis obtained in the previous stage. Data analysis performed includes spatial analysis of the parameters used (Lubis et al., 2017; Anorogo et al. 2017).

The parameter data extracted using remote sensing data is the slope obtained from the ASTER image GDEM data, the 
agricultural land productivity data obtained using NDVI vegetation index transformation and field data on productivity. The growth phase of rice plants has a close relationship with productivity. The relationship is with the greenness level of the rice crop. The association of rice productivity is in the early generative phase. The greenness level of the plant is estimated through the analysis of digital satellite image data using the NDVI formula, and tsunami hazard analysis with various altitude scenarios using run-up model impact on existing agricultural land conditions. The elevation data was obtained from the 15-meter ASTER image data (GDEM) that was reclassified into a slope class map. The elevation is used to calculate areas that will be inundated by tsunami waves and areas potentially reachable by tsunami waves. The greenness of the plant is estimated through the analysis of digital satellite image data using NDVI (Normalized Difference Vegetation Index) used to determine the productivity level of rice crops using the formula:

$(N I R-R e d) /(N I R+R e d)$

wherein the ASTER image data, the infrared channel is channel 3 and the red channel is channel 2. channel 3 is the magnitude of the reflectance value of infrared rays absorbing the wave spectrum coming from the plant (photosynthesis process) and channel 2 is the magnitude of the reflectance value of the red light reflecting wave that comes from plants. This means that the more active the process of photosynthesis (healthy plants) NDVI value will be higher and vice versa the less healthy or lower the greenness of plants (green leaves do not cover the entire surface of the soil and not / less fertile) will give lower NDVI value.

Numerical modeling is performed to determine the run-up height of the tsunami through numerical data. This model can be designed using the worst-case scenario. This information then became the basis for making a tsunami inundation class map. The tsunami inundation model analyzed from the coming wave (run-up) with a height of 30 $\mathrm{m}$. Modeling of tsunami inundation uses scenarios of tsunami run-up height in the coastline, coarse coefficient, and slope. The decrease of water level in each region is calculated by using kriging method through equation (Berryman, 2006):

$$
\text { Hloss }=\left(\frac{167 * n^{2}}{H 0^{\frac{1}{3}}}\right)+5 \sin * S
$$

Where

$\mathrm{H}_{\text {loss }}=$ decrease the water level every meter from the inundation distance

$\mathrm{n}=$ coefficient of surface roughness

$\mathrm{H}_{0}=$ the water level at the shoreline

$\mathrm{S}=$ slope

\section{RESULTS AND DISCUSSION}

The first stage performed in this research is the extraction of remote sensing data to identify the object of agricultural land. Data extraction using multispectral classification method assisted by visual interpretation. The multispectral classification of remote sensing data used is the maximum likelihood classification. The land cover class sought is a class of land covering the purpose of distinguishing between agricultural land and non-agricultural land. The object of this farm is seen in ASTER composite image 321 with dominant pink color, so the result of multispectral classification can be compared with the result of the color composite by comparing the color distribution pattern in each view. The class input of this maximum likelihood classification is the training area used to collect the samples used as the basis for class classification. This training area is taken from the Region of Interest (ROI) by taking samples of each object in one scene image area of the research. The multispectral classification is shown in figure 2 .

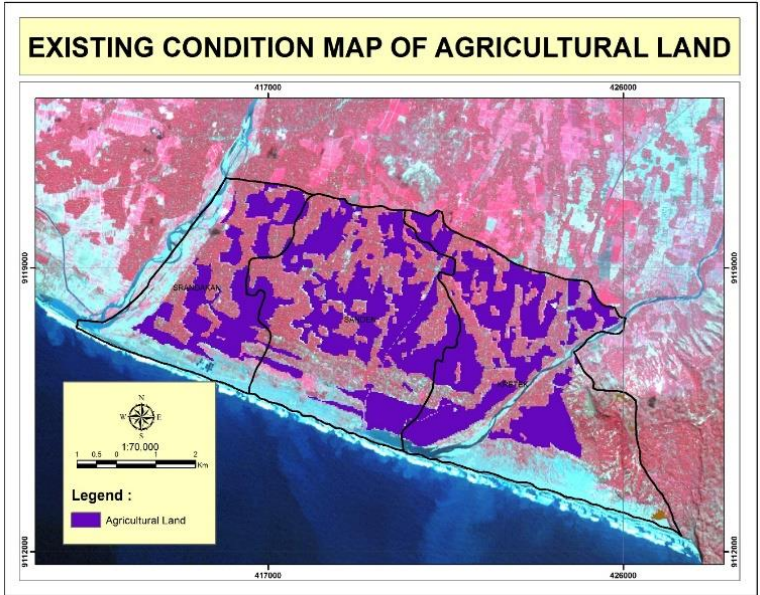

Figure 2. Multispectral classification of agricultural land.

\begin{tabular}{|l|l|l|l|}
\hline Land Cover & $\begin{array}{l}\text { Agricultural } \\
\text { Land }\end{array}$ & $\begin{array}{l}\text { Non- } \\
\text { Agricultural } \\
\text { Land }\end{array}$ & Amount \\
\hline $\begin{array}{l}\text { Agricultural } \\
\text { Land }\end{array}$ & 154 & 8 & 162 \\
\hline $\begin{array}{l}\text { Non- } \\
\text { Agricultural } \\
\text { Land }\end{array}$ & 10 & 213 & 223 \\
\hline Amount & 164 & 221 & 385 \\
\hline Omission & $6,49 \%$ & $3,76 \%$ & \\
\hline Commission & $5195 \%$ & $4,95 \%$ & \\
\hline
\end{tabular}

Table 2. Confusion Matrix Classification

$$
\begin{gathered}
A O I=\frac{\text { Number of Correct Interpretations }}{\text { Total Number of Objects }} \times 100 \% \\
=(367 / 385) \times 100 \%=95,32 \%
\end{gathered}
$$

The next step is to transform the vegetation index that will be used to find the productivity of rice crops. The value of rice plant productivity sought by field survey using NDVI transformation as the basis of field sampling. Sample taking is done by purposive sampling that each class is taken sample based on the goal. Sampling in each class that has the same transformation value assumes that the plant has the same productivity value. The NDVI transformation is shown in figure 3. 


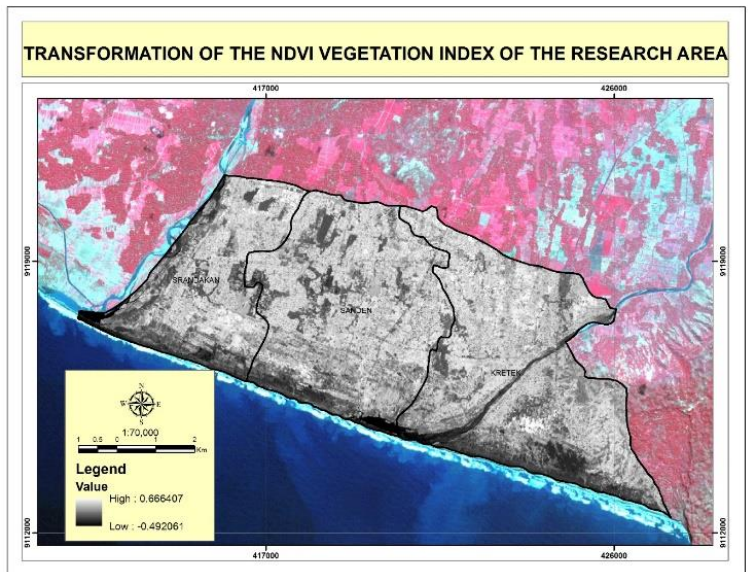

Figure 3. The NDVI transformation.

Data from field sampling result in the data of rice plant productivity then conducted correlation and regression analysis to get productivity estimation result with remote sensing data result of the transformation of vegetation index. This research used half of the total samples taken to build a model of correlation and regression. While the rest of the sample is not used to build the model, it is used to build a test of field data accuracy that has been taken. The sample used to construct the correlation model is shown in table 3 .

\begin{tabular}{|l|l|l|}
\hline No & NDVI & $\begin{array}{l}\text { Productivity } \\
\text { (Ton/Ha/Year })\end{array}$ \\
\hline 2 & 0.277102 & 1.067 \\
\hline 3 & 0.305152 & 1.531 \\
\hline 10 & 0.352466 & 1.971 \\
\hline 11 & 0.31434 & 1.871 \\
\hline 12 & 0.02882 & 1.43 \\
\hline 13 & 0.450521 & 2.757 \\
\hline 21 & 0.373644 & 2.381 \\
\hline 22 & 0.358491 & 2.071 \\
\hline 25 & 0.481 & 2.886 \\
\hline 26 & 0.53062 & 3.586 \\
\hline 27 & 0.361462 & 2.286 \\
\hline 28 & 0.470225 & 2.774 \\
\hline 30 & 0.128359 & 0.857 \\
\hline 31 & 0.551846 & 3.786 \\
\hline 32 & 0.513811 & 3.071 \\
\hline 33 & 0.311226 & 1.731 \\
\hline 34 & 0.081035 & 0.91 \\
\hline 35 & 0.168682 & 0.931 \\
\hline & & \\
& & \\
\hline
\end{tabular}

Table 3. Sample model between NDVI value with rice productivity.
The correlation model built is the relationship between the productivity of the rice plant and the value of the transformation of the vegetation index used. The values of the transformation of the vegetation index are seen from the transformation image of each sample unit, based on the vegetation index values found in each sample coordinate taken. The 2-dimensional matrix of the relationship between NDVI value and rice plant productivity is shown in Figure 3.

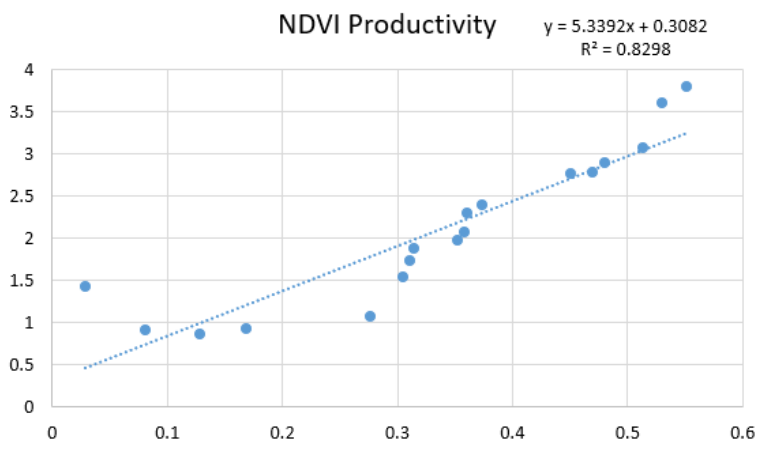

Figure 4. 2-dimensional matrix of the relationship between NDVI value and rice plant productivity

The result of the correlation between NDVI vegetation transformation index value and rice plant productivity show that both variables are related to each other. This is indicated by the magnitude of $\mathrm{R}^{2}$ value on the correlation result of both variables is 0.8298 . The value is large and acceptable when viewed from the number of samples used to construct this model. The number of samples used to build this model is 18 samples, whereas in the appendix diagram table it is mentioned that with the sample number 18 , the minimum value of $\mathrm{R}^{2}$ that can be used is 0.32 , so with the result of $\mathrm{R}^{2}$ value of 0.8298 , then the value can be quite good and the two variables are interconnected.

The last stage is the stage of tsunami wave height modeling. This modeling uses ASTER GDEM data to make it. The waves modeling data is then combined with the estimation data of rice production to obtain risk loss data due to the wave height model that impact on agricultural land. Estimation of tsunami model based on the variation of runup height in the mainland can be done to make tsunami hazard area with wave height $5 \mathrm{~m}, 10 \mathrm{~m}, 15 \mathrm{~m}, 20 \mathrm{~m}$, and $30 \mathrm{~m}$. Tsunami wave modeling in various altitude scenarios shown in Figure 5. 

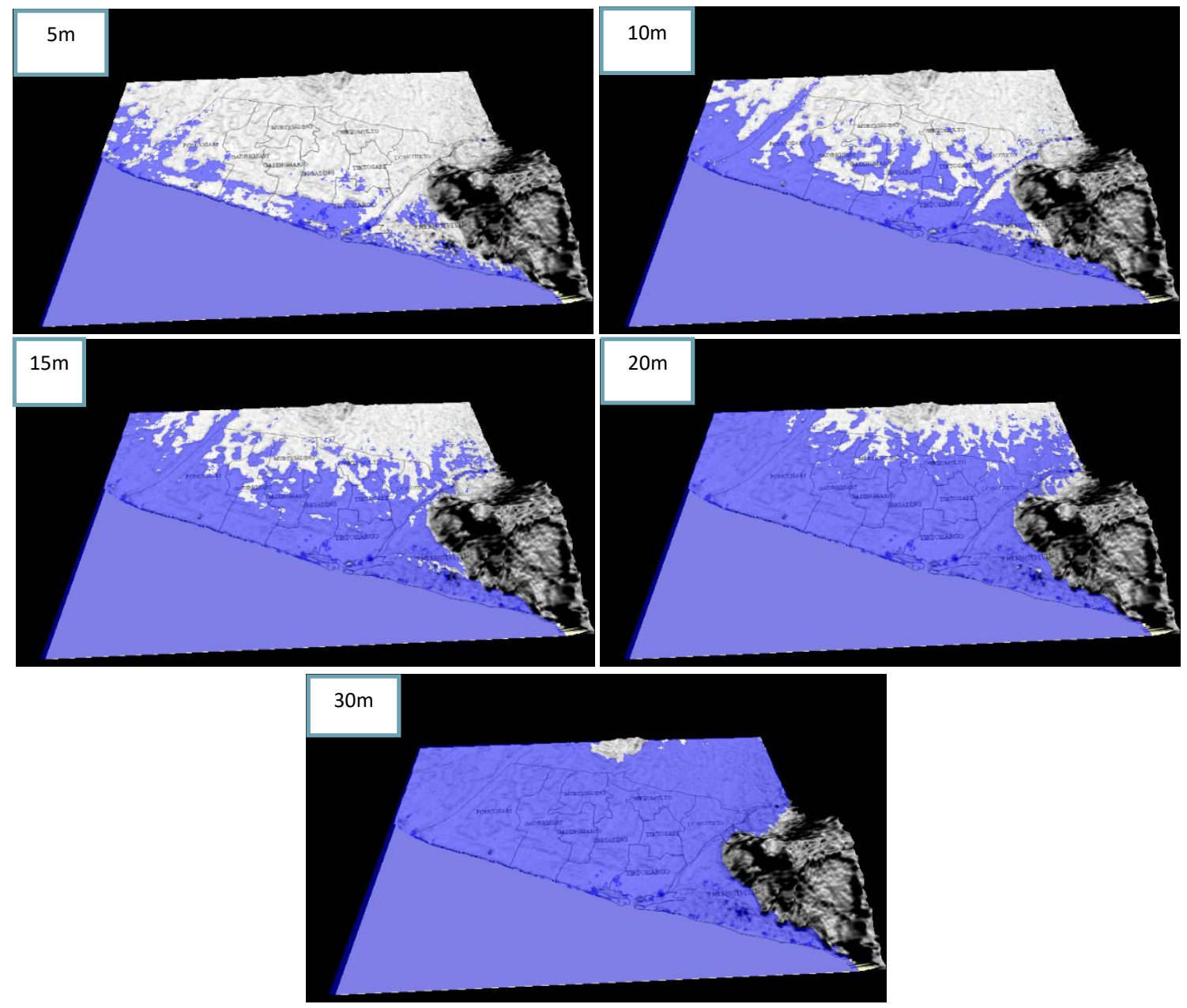

Figure 5. Tsunami wave modeling in various altitude scenarios

The risk index of rice farmland loss in various wave height scenarios is 190,5071 ton for height $1 \mathrm{~m}, 1851,522$ ton for height 5 m, 7402,71 ton for height $10 \mathrm{~m}, 10776,47$ ton for height $15 \mathrm{~m}, 11823,9$ tons for height 20 meters, and 11824.27 tons for a height of 30 meters. The risk of loss of agricultural land based on wave heights is shown in table 4 .

\begin{tabular}{cccccccc}
\hline \multirow{2}{*}{$\begin{array}{c}\mathbf{H} \\
(\mathbf{m})\end{array}$} & $\begin{array}{c}\text { Extent of } \\
\text { farmland } \\
\text { flooded } \\
\text { (Ha) }\end{array}$ & $\begin{array}{c}\text { Risk of } \\
\text { loss } \\
\text { (Ton) }\end{array}$ & & & & & \\
Risk loss based on Rice price (Rp) & & \\
\cline { 4 - 8 } & & & $\mathrm{Rp} 4000 / \mathrm{Kg}$ & $\mathrm{Rp} 4500 / \mathrm{Kg}$ & $\mathrm{Rp} 5000 / \mathrm{Kg}$ & $\mathrm{Rp} 5500 \mathrm{Kg}$ & $\mathrm{Rp} .6000 / \mathrm{Kg}$ \\
\hline $\mathbf{5}$ & 431.552 & 1851.522 & 7406088 & 8331849 & 9257610 & 10183371 & 11109132 \\
\hline $\mathbf{1 0}$ & 1407.504 & 7402.71 & 29610840 & 33312195 & 37013550 & 40714905 & 44416260 \\
\hline $\mathbf{1 5}$ & 2005.279 & 10776.47 & 43105880 & 48494115 & 53882350 & 59270585 & 64658820 \\
\hline $\mathbf{2 0}$ & 2184.66 & 11823.9 & 47295600 & 53207550 & 59119500 & 65031450 & 70943400 \\
\hline $\mathbf{3 0}$ & 2184.724 & 11824.27 & 47297080 & 53209215 & 59121350 & 65033485 & 70945620 \\
\hline
\end{tabular}

Table 4. The risk of loss of agricultural land based on wave heights scenario

\section{CONCLUSION}

Estimation of Tsunami Inundation model based on the variation of altitude run-up on land can be made by using remote sensing data and GIS. GIS applications are used to create tsunami hazard areas with wave heights of $5 \mathrm{~m}, 10 \mathrm{~m}$, $15 \mathrm{~m}, 20 \mathrm{~m}$, and $30 \mathrm{~m}$. The entire research area has been flooded at the height of 21-meter tsunami model. Inundation of the entire research area will result in the risk of loss on agricultural land of 11824.27 tons.

\section{ACKNOWLEDGEMENTS}

This research was supported by Batam state polytechnic. We thank our colleagues Wenang Anurogo and M. Z. Lubis who 
help for providing the data from the study area and expertise that greatly assisted the research.

\section{REFERENCES}

Anurogo, W., Lubis, M.Z., Hartono, H., Pamungkas, D.S and Dilaga, A.P., Kajian Ketahanan Kawasan Wisata Berbasis Masyarakat Dalam Penguatan Ekonomi Lokal Serta Pelestarian Sumberdaya Kebudayaan Kawasan Kotagede Yogyakarta. Jurnal Ketahanan Nasional, 23(2), pp.114-136.

Anurogo, W., Lubis, M.Z., Khoirunnisa, H., Pamungkas, D.S., Hanafi, A., Rizki, F., Surya, G., Situmorang, A.D.L., Timbang, D., Sihombing, P.N. and Lukitasari, C.A., 2017. A Simple Aerial Photogrammetric Mapping System Overview and Image Acquisition Using Unmanned Aerial Vehicles (UAVs). Journal of Applied Geospatial Information, 1(01), pp.11-18.

Anurogo, W., Lubis, M.Z., Pamungkas, D.S. and Ibrahim, F.M., 2017, December. A Spatial Approach to Identify Slum Areas in East Wara Sub-Districts, South Sulawesi. In IOP Conference Series: Earth and Environmental Science (Vol. 98, No. 1, p. 012030). IOP Publishing.

Bantul, B.P.S.K., 2016. Kabupaten Bantul dalam Angka 2016. Jogjakarta: BPS.

Berryman, K., 2006. Review of Tsunami hazard and risk in New Zealand, report by the Institute of Geological and Nuclear Sciences. New Zealand.

Carpenter, G. (2005). Tsunami: Indian Ocean event and investigation into potential global risks. See the report release in March.

Eckert, S., Jelinek, R., Zeug, G. and Krausmann, E., 2012. Remote sensing-based assessment of tsunami vulnerability and risk in Alexandria, Egypt. Applied geography, 32(2), pp.714-723.

Hartoko, A., Helmi, M., Sukarno, M. and Hariyadi, 2016. Spatial tsunami wave modelling for the south Java coastal area, Indonesia. International Journal of Geomate, 11(25), pp.2455-2460.

Khoirunnisa, H., Lubis, M.Z. and Anurogo, W., 2017. The Characteristics of significant wave height and sea surface temperature in the Sunda Strait. Geospatial information, 1(1).

Khomarudin, M.R., Strunz, G., Ludwig, R., Zoßeder, K., Post, J., Kongko, W. and Pranowo, W.S., 2010. Hazard analysis and estimation of people exposure as contribution to tsunami risk assessment in the west coast of Sumatra, the south coast of Java and Bali. Zeitschrift für Geomorphologie, Supplementary Issues, 54(3), pp.337-356.

Koshimura, S., Oie, T., Yanagisawa, H. and Imamura, F., 2009. Developing fragility functions for tsunami damage estimation using numerical model and post-tsunami data from Banda Aceh, Indonesia. Coastal Engineering Journal, 51(03), pp.243-273.

Lubis, M.Z., Anurogo, W., Gustin, O., Hanafi, A., Timbang, D., Rizki, F., Saragih, D.A., Kartini, I.I., Panjaitan, H.C., Yanti, M.T. and Taki, H.M., 2017. Interactive modelling of buildings in Google Earth and GIS: A 3D tool for Urban Planning (Tunjuk Island, Indonesia). Journal of Applied Geospatial Information, 1(2), pp.44-48.

Lubis, M.Z., Anurogo, W., Kausarian, H., Surya, G. and Choanji, T., 2017. Sea Surface Temperature and Wind Velocity in Batam Waters Its Relation to Indian Ocean Dipole (IOD). Journal of Geoscience, Engineering, Environment, and Technology, 2(4), pp.255-263.

Lubis, M.Z., Taki, H.M., Anurogo, W., Pamungkas, D.S., Wicaksono, P. and Aprilliyanti, T., 2017, December. Mapping the Distribution of Potential Land Drought in Batam Island Using the Integration of Remote Sensing and Geographic Information Systems (GIS). In IOP Conference Series: Earth and Environmental Science (Vol. 98, No. 1, p. 012012). IOP Publishing.

Matsumaru, R., Nagami, K. and Takeya, K., 2012. Reconstruction of the Aceh Region following the 2004 Indian Ocean tsunami disaster: A transportation perspective. IATSS research, 36(1), pp.11-19.

Nugraha, A.D., Shiddiqi, H.A., Widiyantoro, S., Ramdhan, M., Wandono, Sutiyono, Handayani, T. and Nugroho, H., 2015, April. Preliminary results of teleseismic double-difference relocation of earthquakes around Indonesian archipelago region. In AIP Conference Proceedings (Vol. 1658, No. 1, p. 030002). AIP Publishing.

Pomeroy, R.S., Ratner, B.D., Hall, S.J., Pimoljinda, J. and Vivekanandan, V., 2006. Coping with disaster: rehabilitating coastal livelihoods and communities. Marine Policy, 30(6), pp.786-793.

Reese, S., Cousins, W.J., Power, W.L., Palmer, N.G., Tejakusuma, I.G. and Nugrahadi, S., 2007. Tsunami vulnerability of buildings and people in South Java? Field observations after the July 2006 Java tsunami. Natural Hazards and Earth System Science, 7(5), pp.573-589.

Rizki, F., Situmorang, A.D.L., Wau, N., Lubis, M.Z. and Anurogo, W., 2017. Mapping Of Vegetation and Mangrove Distribution Level in Batam Island Using SPOT-5 Satellite Imagery. Journal of Geoscience, Engineering, Environment, and Technology,2(4), pp.264-267.

Shalaby, A. and Tateishi, R., 2007. Remote sensing and GIS for mapping and monitoring land cover and land-use changes in the Northwestern coastal zone of Egypt. Applied Geography, 27(1), pp.28-41. 
Tumonggor, M.K., Karafet, T.M., Hallmark, B., Lansing, J.S., Sudoyo, H., Hammer, M.F. and Cox, M.P., 2013. The Indonesian archipelago: an ancient genetic highway linking Asia and the Pacific. Journal of human genetics, 58(3), p.165.

Wang, X. and Liu, P.L.F., 2006. An analysis of 2004 Sumatra earthquake fault plane mechanisms and Indian Ocean tsunami. Journal of Hydraulic Research, 44(2), pp.147-154. 